\title{
Development of new technology for coal gasification purification and research on the formation mechanism of pollutants
}

\author{
Shu Zheng ${ }^{1, *}$, Yixiang $\mathrm{Shi}^{2}$, Zhiqi Wang ${ }^{3}$, Gang Liu ${ }^{4}$, Huaichun Zhou ${ }^{5}$ \\ ${ }^{1}$ National Engineering Laboratory for Biomass Power Generation Equipment, North China Electric \\ Power University, Beijing 102206, China \\ ${ }^{2}$ Key Laboratory for Thermal Science and Power Engineering of Ministry of Education, Department \\ of Energy and Power Engineering, Tsinghua University, Beijing 100084, China \\ ${ }^{3}$ Qingdao Institute of Bioenergy and Bioprocess Technology, Chinese Academy of Sciences, Qingdao \\ 266101, China \\ ${ }^{4}$ State Key Laboratory of Clean Coal-based Energy, China Huaneng Group Clean Energy Research \\ Institute Co., Ltd., Changping District, Beijing 102209, China \\ ${ }^{5}$ School of Energy and Power Engineering, Northeast Electric Power University, Jilin 132012, China \\ *Corresponding author. E-mail: shuzheng@ncepu.edu.cn
}

\begin{abstract}
Coal-fired power generation is the main source of $\mathrm{CO}_{2}$ emission in China. To solve the problem of efficiency decline and cost increase caused by $\mathrm{CO}_{2}$ capture of coal-fired power generation, Prof. Peng (Peng and Han 2009) proposed an integrated gasification fuel cell (IGFC) power generation technology. The interaction mechanism of coal gasification purification, fuel cell and other components need to be further study in the IGFC. To develop new technology for coal gasification and purification, we studied gasification reaction characteristics of ultrafine coal particles, ash melting characteristics and effects on coal gasification reaction, the formation mechanism of pollutants and developed an elevated temperature pressure swing adsorption rig for $\mathrm{H}_{2} \mathrm{~S}$ and $\mathrm{CO}_{2}$ simultaneous removal. The results show that the Miura-Maki model appropriate to perform gasification kinetics of Shenhua bituminous coal and the predicted DTG curves fit the experimental data well. The designed 8-6-1 cycle procedure can effectively remove $\mathrm{CO}_{2}$ and $\mathrm{H}_{2} \mathrm{~S}$ simultaneously, and the removal rate is over $99.9 \%$. In addition, the transition metal oxides used as mercury removal adsorbents in coal gasification syngas has great potential. The technique presented in this paper can improve the gasification efficiency and reduce the formation of pollutants for IGFC.
\end{abstract}

Keywords: IGFC; coal gasification; $\mathrm{H}_{2} \mathrm{~S}-\mathrm{CO}_{2}$ removal; syngas mercury removal

\section{Introduction}

Entrained flow coal gasification technology, whose carbon conversion rate and cold gas efficiency can be as high as $98 \%$ and $80 \%$ respectively, represent the direction of coal gasification. Liquid slagging and dry feeding coal gasification technology has many advantages such as low oxygen consume, high carbon conversion, high cold gas efficiency, and large capacity for single furnace, which will be the mainstream of advanced coal gasification (Liu and Tian 2012). Pulverized coal with Low ash melting point has often been used in dry feeding entrained flow gasification. Gasifying temperature should be higher than ash melting 
point to ensure the liquid ash removal (Krishnamoorthy and Pisupati 2015). The successful development of large energy efficient ultrafine pulverized coal preparation system establishes the foundation for the utilization of ultrafine pulverized coal. Microscale effect of ultrafine pulverized coal can increase the gasification rate and conversion efficiency (Liu et al. 2014; Luo et al. 2019). This paper intends to perform the research on gasification characteristics of ultrafine pulverized coal under $\mathrm{CO}_{2}$ atmosphere, and describe the basic kinetic characteristics of ultrafine pulverized coal, to provide theoretical guidance for achieving higher effective gas yield, carbon conversion rate and cold gas efficiency.

At present, the general coal gasification reaction model does not consider the thermal deactivation effect of coal at high temperature, high pressure and high conversion rate. The most commonly used kinetic models for coal gasification reaction include homogeneous model, core-shrinking reaction model and random hole model. Homogeneous model can only describe the process in which the rate of gasification reaction decreases monotonously with the rate of carbon conversion. However, it is not applicable to the gasification process with extreme gasification reaction rate. Although the stochastic pore model can describe the extreme gasification reaction rate, it is not suitable to describe the catalytic gasification process of coal and the extreme value of gasification reaction rate occurs in the case of high conversion rate. So far, no model can accurately describe the process of gasification reaction rate changing with reaction time and conversion rate. Therefore, the establishment of a generalized and quantitative kinetic model to describe coal gasification reaction will be the focus of coal gasification reaction dynamics research.

The distributed activation energy model (DAEM) (Pitt 1962) and carbon burnout kinetic model (CBK) (Cloke et al. 2003; Hurt et al. 1998a; Hurt et al. 1998b) have been proven very successful for describing the kinetics of coal pyrolysis and combustion. The DAEM was originally proposed by Pitt (Pitt 1962) and was later adapted by Anthony and Howard (Anthony and Howard 1976). It describes a complex reaction as a number of parallel first-order reactions, each occurring with its own rate coefficient. Usually, it is further assumed that all reactions share the same frequency factor and that measuring the relationship between the distributed activation energy and the burnout ratio requires at least three different heating rates. The CBK model was proposed by Hurt (Hurt et al. 1998b). It accurately describes the kinetics of heterogeneous char oxidation reactions. One of the main limitations of this type of research is that burning and burnout temperatures are always lower than the ash flow temperature (AFT). The kinetic characteristics of coal high-temperature combustion require further investigation. In this study, the kinetic parameters of the char combustion including the activation energy (E) and pre-exponential factor (A) were obtained from thermogravimetric analyzer (TGA) data. A model that predicted the char combustion rate was then established using the kinetic parameters of char combustion and was validated with experimental data.

In the field of syngas purification, there are several industrialized methods which could separately remove $\mathrm{H}_{2} \mathrm{~S}$ and $\mathrm{CO}_{2}$, such as Selexol, methyldiethanolamine (MDEA), rectisol and pressure swing adsorption (PSA) (Chaubey et al. 2013; Dincer and Acar 2015; Wiheeb et al. 2013; $\mathrm{Yu}$ et al. 2012). These techniques are widely used in coal chemical industry, providing a basis for the development of $\mathrm{H}_{2} \mathrm{~S}-\mathrm{CO}_{2}$ simultaneous removal methods. Selexol, rectisol and MDEA belong to wet method, in which impurities are absorbed by solvents at $-50 \sim 60 \mathrm{~K}$. The solvent in MDEA is chemical absorbent while the others are physical absorbent. The devices of wet methods are complicated and costly. Impurity 
removal and absorbents regeneration are conducted in different units. The maintenance and operating costs are not economical either.

Therefore, some substitutes of conventional purification methods are proposed and studied. Using dry methods, RTI international (Denton and L 2014; Gupta and Raghubir 2010) separated $\mathrm{H}_{2} \mathrm{~S}$ and $\mathrm{CO}_{2}$ from syngas at elevated temperature and normal temperature, respectively, more than $99.9 \%$ of the $\mathrm{H}_{2} \mathrm{~S}$ and $90 \%$ of the $\mathrm{CO}_{2}$ being captured. Compared with Selexol and rectisol, the initial investment of this method decreased by $50 \%$ and the operating cost was also lower. The energy consumption of adsorbent/absorbent regeneration is only $72 \%$ of that in Selexol.

Moreover, if $\mathrm{H}_{2} \mathrm{~S}$ and $\mathrm{CO}_{2}$ could be simultaneously removed in one step, the device would be further simplified. However, the corresponding techniques are still under development. Improvement of adsorbent performance, technique process design and adsorption bed structure optimization are all necessary at this stage.

With the rapid development of human society, energy and environmental problems are becoming more and more serious. However, China's rich in coal, poor in oil and gas determines that coal will be the main fossil energy to maintain the rapid development of the whole society in a long period of development. Accordingly, sulfur, nitrogen, chlorine and other pollutants generated in the process of coal utilization have been widely concerned $(\mathrm{Xu}$ and Wei 1999); The trace and volatile metal elements (such as $\mathrm{Hg}, \mathrm{Pb}, \mathrm{As}$, Se, etc.) has also been paid more attention. Mercury is the most volatile heavy metal pollutant in coal. Although its concentration in coal is relatively low, the output and consumption of coal are very large, and mercury is mainly discharged in the form of gas, so the mercury discharged in the process of coal utilization accounts for a large proportion of the mercury released by human activities.
With more and more attention paid to the mercury pollution in the air, the mercury emission in the process of coal utilization has become an urgent environmental problem to be solved. There are three forms of mercury released from coal utilization: $\mathrm{Hg}^{\mathrm{p}}, \mathrm{Hg}^{2+}$ and $\mathrm{Hg}^{0}$. $\mathrm{Hg}^{\mathrm{p}}$ can be removed by particulate control equipment, $\mathrm{Hg}^{2+}$ can be removed by wet scrubbing or $\mathrm{SO}_{2}$ control equipment, while elemental mercury is not easy to dissolve, so it is difficult to remove it by ordinary dust removal equipment (Pavlish et al. 2003). In recent years, the research work of mercury removal mainly focuses on the removal of mercury from coal-fired flue gas. The main methods are: (1) Adsorption method: adsorption of mercury in flue gas with activated carbon, fly ash, mineral adsorbents, etc. (Granite et al. 2000; Liu 2015); (2) Catalytic adsorption method: metal oxides (such as $\mathrm{TiO}_{2}, \mathrm{CeO}_{2}, \mathrm{ZnO}, \mathrm{MoO}_{3}, \mathrm{Cuo}, \mathrm{MnO}_{2}$, etc.) ( $\mathrm{Li}$ et al. 2011; Liu 2016; Wen et al. 2011) or precious metals (Ag, $\mathrm{Pd}, \mathrm{Pt}$, etc.) (Liu et al. 2008) are loaded on $\mathrm{Al}_{2} \mathrm{O}_{3}$ or molecular sieve and other carriers to remove mercury. The two methods show a certain ability of mercury removal in different temperature ranges, but the components of flue gas $\left(\mathrm{SO}_{2}, \mathrm{SO}_{3}\right.$, no, $\mathrm{NOx}$, $\mathrm{HCl}$, etc.) have a great influence on the mechanism of mercury removal. The gas produced by coal gasification is composed of reducing atmosphere (usually containing trace $\mathrm{O}_{2}$ ), and the content of elemental mercury that is difficult to remove is higher than that of coal-fired flue gas (Pavlish et al. 2003; Reed et al. 2001). Therefore, the removal of mercury from coal gas atmosphere has gradually become a research hotspot at home and abroad, and the Research of mercury removal is the key of efficient mercury removal technology.

\section{Methods and Experiments}

\section{1 $\mathrm{CO}_{2}$ gasification of ultrafine coal particles}

Bituminous coal obtained from Shenhua 
mine was used in this work. Screening equipment was used to separate materials with five particle sizes, and their average particle sizes were determined by Malvern Mastersizer 3000. Thermogravimetric analysis was conducted with a TG (Setsys Evolution, SETARAM, France). Each sample was heated under $\mathrm{CO}_{2}$ atmosphere from ambient temperature to $1300{ }^{\circ} \mathrm{C}$ with four different heating rates $\left(5,10,20\right.$, and $\left.40{ }^{\circ} \mathrm{C} / \mathrm{min}\right)$. The integral iso-conversional model proposed by Miura-Maki (Miura and Maki 1998) was used to perform the kinetic analysis.

$\ln \left(\frac{\beta}{T^{2}}\right)=\ln \left(\frac{k_{0} R}{E}\right)+0.6075-\frac{E}{R T}$

Where $\beta$ is the heating rate; $k_{0}$ is the pre-exponential factor; $E$ is the activation energy; $R$ is the universal gas constant; $T$ is the absolute temperature $(\mathrm{K})$.

\subsection{Model building of coal gasification}

\subsubsection{Kinetic model of char combustion}

At low combustion reaction temperatures, the chemical reaction rate is not very fast and the oxygen supply rate is much faster than the chemical reaction oxygen consumption rate. Therefore, the combustion process consisted of slow heating and the combustion reaction zone can be considered a dynamic area, where the chemical kinetic factors control the reaction rate (Sun and Chen 1991). The reaction rate can be expressed with the Arrhenius law and the assumptions are as follows (Zhang et al. 2000):

(a) The sample particles are spherical, and the particle diameter and density are constant during the combustion process, the impact of the ash layer on the combustion is not considered.

(b) The combustion reactions only occur on the particles' surfaces and the reaction rate is calculated based on the particles' outside surface area.

(c) The oxygen pressure is distributed evenly throughout the sample layer.

(d) The total surface reaction product is
$\mathrm{CO}_{2}$.

The combustion rate function can be expressed as follows (Hecker et al. 2003; Sima-Ella et al. 2005):

$\alpha=\frac{m_{0}-m}{m_{0}-m_{\infty}}$

$-\frac{d \alpha}{d \mathrm{t}}=K(\alpha) \alpha$

The reaction rate function $K(\alpha)$ is usually assumed to be the Arrhenius equation(Pilling and Seakins 1995):

$$
K(\alpha)=A(\alpha) \exp (-E(\alpha) /(R T))
$$

where $\alpha$ is the burnout ratio, which is the mass fraction of the burned combustible matter with the total combustible matter in the coal; $\mathrm{m}_{0}$ is the initial mass weight of the sample; $m$ is the sample's mass weight at time $t$ and $m_{\infty}$ is the final sample weight; $K(\alpha)$ is the combustion reaction rate as a function of $\alpha ; A(\alpha)$ is the pre-exponential factor function; $E(\alpha)$ is the activation energy function; $T$ is the combustion temperature; $R$ is the gas coefficient.

The curves of char combustion at two temperatures $T_{1}$ and $T_{2}$ can be obtained from TGA experiments including $T G_{l}(\alpha), T G_{2}(\alpha)$, $D T G_{l}(\alpha)$, and $D T G_{2}(\alpha)$. The $E(\alpha)$ and $A(\alpha)$ from $T_{1}$ to $T_{2}$ can be calculated as:

$E_{\mathrm{T}_{1}-\mathrm{T}_{2}}(\alpha)=-\frac{R \ln \frac{D T G_{1}(\alpha)}{D T G_{2}(\alpha)}}{\left(\frac{1}{T_{1}}-\frac{1}{T_{2}}\right)}$

$A_{\mathrm{T}_{1}-\mathrm{T}_{2}}(\alpha)=\frac{D T G_{2}(\alpha)}{\exp \left(-E_{\mathrm{T}_{1}-\mathrm{T}_{2}}(\alpha) /\left(R T_{2}\right)\right)}$

From Eqs. (5) and (6), the predicted combustion reaction rate function $D T G^{\prime}(\alpha)$ at a combustion temperature of $T_{3}\left(T_{3} \in\left[T_{1}, T_{2}\right]\right)$ follows:

$D T G^{\prime}(\alpha)=A_{\mathrm{T}_{1}-\mathrm{T}_{2}}(\alpha) \exp \left(-E_{\mathrm{T}_{1}-\mathrm{T}_{2}}(\alpha) / R T_{3}\right)$

To validate the predicted model's veracity, the predicted results are compared with 
experimental data and an error analysis is conducted.

2.2.2 Coal Properties and Experimental Method

Hulunbeier lignite coal was utilized in the present work. The average diameter of the coal samples was $76 \mu \mathrm{m}$ and all samples were less than $200 \mu \mathrm{m}$. The coal properties, ash components, and fusion characteristic temperatures are presented in Table $\mathbf{1}$

Table 1 Coal properties (as received basis, wt.\%) and ash components analysis

\begin{tabular}{|c|c|c|c|}
\hline Item & Value & Item & Value \\
\hline Coal proximate analysis & & Ash compositions & \\
\hline$(\%, w / w$ ar $)$ & & (wt \%) & \\
\hline Fixed carbon & 44.86 & $\mathrm{SiO}_{2}$ & 55.63 \\
\hline Volatile matter & 35.44 & $\mathrm{Al}_{2} \mathrm{O}_{3}$ & 11.51 \\
\hline Ash & 11.05 & $\mathrm{Fe}_{2} \mathrm{O}_{3}$ & 14.22 \\
\hline Moisture & 8.65 & $\mathrm{CaO}$ & 11.24 \\
\hline Ultimate analysis & & $\mathrm{MgO}$ & 2.14 \\
\hline$(\%, \mathrm{w} / \mathrm{w}$ ar $)$ & & $\mathrm{TiO}_{2}$ & 0.76 \\
\hline Carbon & 59.46 & $\mathrm{SO}_{3}$ & 3.02 \\
\hline Hydrogen & 3.35 & $\mathrm{P}_{2} \mathrm{O}_{5}$ & 0.06 \\
\hline Oxygen & 16.44 & $\mathrm{~K}_{2} \mathrm{O}$ & 0.48 \\
\hline Nitrogen & 0.80 & $\mathrm{Na}_{2} \mathrm{O}$ & 0.94 \\
\hline Sulfur & 0.25 & Fusion characteristic temperature & \\
\hline Lower heating value & 25.6 & $\left({ }^{\circ} \mathbf{C}\right)$ & \\
\hline \multirow[t]{4}{*}{$(\mathrm{MJ} / \mathrm{kg})$} & & $\mathrm{DT}^{\mathrm{a}}$ & 1090 \\
\hline & & $\mathrm{ST}^{\mathrm{b}}$ & 1100 \\
\hline & & $\mathrm{HT}^{\mathrm{c}}$ & 1110 \\
\hline & & $\mathrm{FT}^{\mathrm{d}}$ & 1160 \\
\hline
\end{tabular}

${ }^{a}$ Deformation Temperature. ${ }^{b}$ Softening Temperature. ${ }^{\mathrm{c}}$ Hemispherical Temperature. ${ }^{\mathrm{d}}$ Flow Temperature.

A TGA from Beijing Henven Scientific Instrument Factory was used. The minimum sensitivity was $0.1 \mu \mathrm{g}$ and the data was collected every second in a temperature range of $25^{\circ} \mathrm{C}$ to $1450^{\circ} \mathrm{C}$.

All coal samples were measured at $20 \mathrm{mg}$, dewatered at $100{ }^{\circ} \mathrm{C}$ for $30 \mathrm{~min}$, and heated at a fixed heating rate of $80^{\circ} \mathrm{C} / \mathrm{min}$ starting at $100^{\circ} \mathrm{C}$ and rising to the temperature $T_{H}$ with $\mathrm{N}_{2}$ atmosphere $(200 \mathrm{~mL} / \mathrm{min})$; the samples were then held at $T_{H}$ for $30 \mathrm{~min}$ for complete volatile devolatilization. Air $(100 \mathrm{~mL} / \mathrm{min})$ was then injected into the TGA after $30 \mathrm{~min}$ and the temperature was kept constant until the mass weights of the samples remained constant. The temperature $T_{H}$ in each case was divided into 25 levels in the range of $500 \sim 1450{ }^{\circ} \mathrm{C}$, and using intervals of $50{ }^{\circ} \mathrm{C}$ in the range of $500 \sim 1200{ }^{\circ} \mathrm{C}$ and $25^{\circ} \mathrm{C}$ in the range of $1200 \sim 1450{ }^{\circ} \mathrm{C}$.

\section{$2.3 \mathrm{H}_{2} \mathrm{~S}-\mathrm{CO}_{2}$ removal}

The authors had proposed elevated temperature pressure swing adsorption (ETPSA) process operating at $150 \sim 400{ }^{\circ} \mathrm{C}$ for $\mathrm{H}_{2} \mathrm{~S}-\mathrm{CO}_{2}$ simultaneous removal. It is similar to PSA but the working temperature is higher. As a dry method, the device of ETPSA is less complex 
than that in wet methods. Furthermore, compared with regular PSA, ETPSA is more energy efficiency due to a higher product gas recovery rate and less sensible heat loss (Gazzani et al. 2013).

A small scale $\left(6 \mathrm{Nm}^{3} / \mathrm{h}\right)$ ETPSA unit has been developed in in the ammonia plant of Quanji Energy Co., Ltd., Shanxi province, China. On-site $\mathrm{CO}_{2}-\mathrm{H}_{2} \mathrm{~S}$ simultaneous removal is realized on this device. Syngas coming from water gas shift (WGS) unit flowed to this unit with a flow rate of $1 \sim 10 \mathrm{Nm}^{3} / \mathrm{h}$. The WGS is approximately $50 \mathrm{~m}$ away from ETPSA, hence the temperature decreased from $216^{\circ} \mathrm{C}$ to around $180^{\circ} \mathrm{C}$ during the transport. A part of steam condensed and separated by a gas-liquid separator. The compositions of final feed gas are listed in Table 2.

Table 2 Details of the feed gas

\begin{tabular}{ccc}
\hline Temperature & Pressure & Composition \\
\hline \multirow{2}{*}{$180^{\circ} \mathrm{C}$} & $2-3 \mathrm{MPa}$ & $54 \% \mathrm{H}_{2}, 36 \% \mathrm{CO}_{2}, 5 \% \mathrm{H}_{2} \mathrm{O}, 0.4 \% \mathrm{CO}, 700 \mathrm{ppm} \mathrm{H}_{2} \mathrm{~S}, 1 \% \mathrm{~N}_{2}, 3 \%$ \\
& & $\mathrm{CH}_{4}$, Trace $\mathrm{Ar}$ \\
\hline
\end{tabular}

There were four adsorption beds and four buffer tanks (same sized column packed with similar sized $\mathrm{SiO}_{2}$ particles) in this rig. The tanks are used for pressure equalization. The height of adsorption beds are $1.8 \mathrm{~m}$ and the inner diameter is $79 \mathrm{~mm}$. The adsorbent was $207 \mathrm{C}$ activated carbon (Calgon Carbon Co., Ltd) which had undergone some special surface treatment(Li et al. 2019). The hydrophobicity of the adsorbent was much more better than the pristine activated carbon. The outlook of this rig is given by Fig.

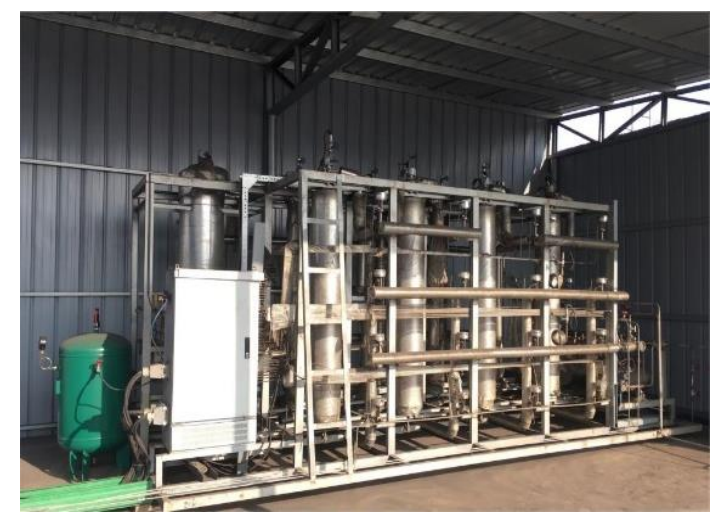

Fig. 1 The outlook photo of ETPSA device 1.

\begin{tabular}{|c|c|c|c|c|c|c|c|c|c|c|c|c|c|c|c|c|c|c|c|c|c|c|c|c|}
\hline Step & 1 & 2 & 3 & 4 & 5 & 6 & 7 & 8 & 9 & 10 & \begin{tabular}{|l|}
11 \\
\end{tabular} & \begin{tabular}{|l|}
12 \\
\end{tabular} & 13 & 14 & 15 & 16 & 17 & 18 & 19 & 20 & 21 & 22 & 23 & 24 \\
\hline Bed1 & $\mathrm{AD}$ & AD & $\mathrm{AD}$ & $A D$ & $A D$ & $\mathrm{RH}$ & PEA & PE1 & PEB & PEC & PE2 & PED & $\mathrm{BD}$ & PG & $\mathrm{V}$ & PED & PE2 & PEC & PEB & PE1 & PEA & PP & PP & $\mathrm{PP}$ \\
\hline $\operatorname{Bed} 2$ & $\mathrm{~EB}$ & PE1 & PEA & PP & PP & PP & AD & AD & AD & $\mathrm{AD}$ & AD & $\mathrm{RH}$ & PEA & PE1 & PEB & PEC & PE2 & PED & $\mathrm{BD}$ & PG & V & PED & PE2 & PEC \\
\hline Bed3 & $\mathrm{BD}$ & PG & $\mathrm{V}$ & PED & PE2 & PEC & PEB & PE1 & PEA & PP & PP & PP & $\mathrm{AD}$ & $\mathrm{AD}$ & $\mathrm{AD}$ & AD & $\mathrm{AD}$ & $\mathrm{RH}$ & PEA & PE1 & PEB & PEC & PE2 & PED \\
\hline Bed4 & PEA & PE1 & PEB & PEC & PE2 & PED & $\mathrm{BD}$ & PG & $\mathrm{V}$ & PED & PE2 & PEC & PEB & PE1 & PEA & PP & $\mathrm{PP}$ & PP & AD & $\mathrm{AD}$ & $\mathrm{AD}$ & $\mathrm{AD}$ & $\mathrm{AD}$ & $\mathrm{RH}$ \\
\hline Tank1 & PEA & & PEA & & & & PEA & & PEA & & & & PEA & & PEA & & & & PEA & & PEA & & & \\
\hline Tank2 & PEB & & PEB & & & & PEB & & PEB & & & & PEB & & PEB & & & & PEB & & PEB & & & \\
\hline Tank3 & & & & PEC & & PEC & & & & PEC & & PEC & & & & PEC & & $\mathrm{PEC}$ & & & & PEC & & PEC \\
\hline Tank4 & & & & $\mathrm{PED}$ & & $\mathrm{PED}$ & & & & PED & & PED & & & & PED & & $\mathrm{PED}$ & & & & PED & & $\mathrm{PED}$ \\
\hline $\mathrm{Cycl}$ & 50 & 30 & 14 & 14 & 14 & 14 & 50 & 30 & 14 & 14 & 14 & 14 & 50 & 30 & 14 & 14 & 14 & 14 & 50 & 30 & 14 & 14 & 14 & 14 \\
\hline $\mathrm{Cycl}$ & 43 & 19 & 13 & 13 & 13 & 13 & 43 & 19 & 13 & 13 & 13 & 13 & 43 & 19 & 13 & 13 & 13 & 13 & 43 & 19 & 13 & 13 & 13 & 13 \\
\hline Cycle & 34 & 18 & 11 & 11 & 11 & 5 & 34 & 18 & 11 & 11 & 11 & 5 & 34 & 18 & 11 & 11 & 11 & 5 & 34 & 18 & 11 & 11 & 11 & 5 \\
\hline Cycle 468s & 40 & 25 & 14 & 15 & 15 & 7 & 40 & 25 & 14 & 15 & 15 & 7 & 40 & 25 & 14 & 15 & 15 & 7 & 40 & 25 & 14 & 15 & 15 & 7 \\
\hline
\end{tabular}

Fig. 2 8-6-1 ETPSA cycle procedures. AD: adsorption; RH: high pressure steam rinse; PE: pressure equalization with columns $(1,2)$ or tanks $(\mathrm{A}, \mathrm{B}, \mathrm{C}, \mathrm{D})$; BD: counter-current blow down; PG: $\mathrm{N}_{2}$ purge; $\mathrm{V}$ : vacuum desorption; $\mathrm{PP}$ : pressurization with product gas.

According to elevating the working temperature, the reversibility of $\mathrm{H}_{2} \mathrm{~S}$ adsorption was improved (Hao et al. 2019). Adsorbed $\mathrm{H}_{2} \mathrm{~S}$ could be detached from the adsorbent and 
collected during vacuum desorption or purge step. Although the sulfur capacity of activated carbon was lower than metal oxides, the breakthrough times of $\mathrm{H}_{2} \mathrm{~S}$ was still much longer than $\mathrm{CO}_{2}$. Hence as long as $\mathrm{CO}_{2}$ did not penetrate the adsorption bed, the $\mathrm{H}_{2} \mathrm{~S}$ could be removed thoroughly.

Herein, an 8-6-1 (eight adsorption beds/tanks, six pressure equalization, one adsorption in each cycle) ETPSA cycles were designed. The schedules are shown in Fig. 2, where the step sequence and the corresponding duration lengths are listed. The time length of each cycle here is $468 \mathrm{~s}$ (the last line in the chart). Because $\mathrm{N}_{2}$ is a material of ammonia synthesis, $\mathrm{N}_{2}$ purging was adopted in this study.

\subsection{Syngas mercury removal}

\subsubsection{Preparation of Adsorbents}

The precursor $\mathrm{Mn}\left(\mathrm{NO}_{3}\right)_{2} \bullet 4 \mathrm{H}_{2} \mathrm{O}$ of $10 \mathrm{~g}$ manganese oxide was dissolved in deionized water, and the volume was fixed in a $100 \mathrm{ml}$ volumetric bottle to prepare $100 \mathrm{ml} \mathrm{Mn}\left(\mathrm{NO}_{3}\right)_{2}$ solution with a mass fraction of $10 \mathrm{wt} . \% .10 \mathrm{~g}$ activated alumina and $10 \mathrm{ml}$ manganese nitrate aqueous solution were measured. Then the activated alumina was added to manganese nitrate aqueous solution, stirred manually for 30 min, and then subjected to ultrasonic shock for $20 \mathrm{~min}$. The activated alumina impregnated with manganese nitrate solution was heated on the electric furnace of $200 \mathrm{~W}$ and placed in the oven of $100{ }^{\circ} \mathrm{C}$ for $1 \mathrm{~h}$ until the water evaporated. After drying, alumina loaded with manganese oxide precursor was placed in a tubular furnace at a constant temperature of $400{ }^{\circ} \mathrm{C}$, and then removed after calcining for $3 \mathrm{~h}$ in an air atmosphere. It was cooled to room temperature in a drying dish. The obtained $\mathrm{Mn}_{2} \mathrm{O}_{3} / \mathrm{Al}_{2} \mathrm{O}_{3}$ mercury removal adsorbent was stored in silica gel.

$\mathrm{Co}_{2} \mathrm{O}_{3} / \mathrm{Al}_{2} \mathrm{O}_{3}$ and $\mathrm{Fe}_{2} \mathrm{O}_{3} / \mathrm{Al}_{2} \mathrm{O}_{3}$ adsorbents were prepared by the same method with $\mathrm{Co}\left(\mathrm{NO}_{3}\right)_{2}$ and $\mathrm{Fe}\left(\mathrm{NO}_{3}\right)_{2}$ as precursors, respectively.

2.4.2 The Device and Method of Adsorbents Evaluation

The experiment was carried out on the fixed bed reactor system, as shown in Fig. 3. It mainly includes 6 parts: simulated syngas control system, mercury vapor generation system, water vapor generation system, tubular reactor system, tail gas treatment system and mercury analysis system. The MAX-L cold atomic absorption mercury analyzer produced by Labtech company was used in the experiment to test the mercury concentration.

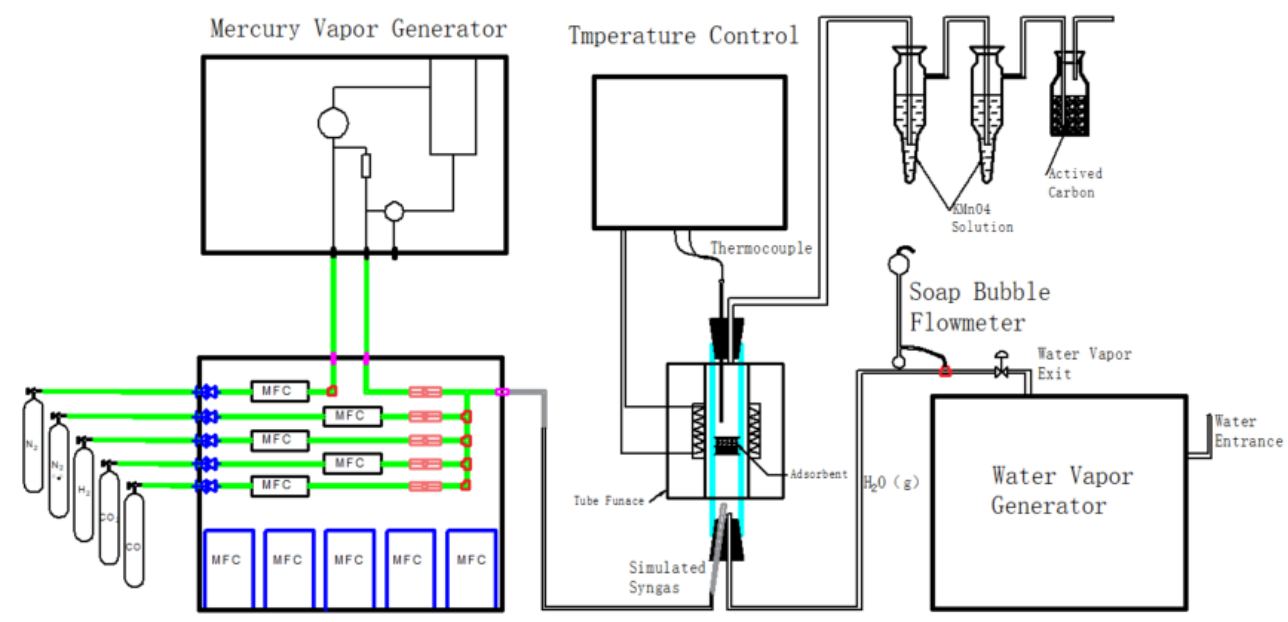

Fig. 3 Schematic diagram of simulated syngas mercury removal system 
The mercury removal activity of the adsorbent was evaluated in a fixed bed reactor under $\quad 200 \quad{ }^{\circ} \mathrm{C} \quad$ simulated gas $\left(\mathrm{N}_{2}-\mathrm{CO}-\mathrm{H}_{2}-\mathrm{H}_{2} \mathrm{~S}-\mathrm{H}_{2} \mathrm{O}-\mathrm{Hg}\right)$ atmosphere, and the experimental apparatus was shown in Fig. 4. Simulated gas was selected in the experiment: $\mathrm{Hg}$ steam concentration was $60 \mu \mathrm{g} / \mathrm{m}^{3}$, stable concentration was provided by mercury permeation tube through the dynamic gas calibration instrument, the permeation temperature was set at $60{ }^{\circ} \mathrm{C}$, the carrier gas was $\mathrm{N}_{2}$, and the flow rate was $200 \mathrm{~mL} / \mathrm{min}$. The simulated gas was provided by standard gas distribution cylinder, $\mathrm{H}_{2} \mathrm{~S}$ concentration of 200 ppm, $\mathrm{H}_{2}$ volume fraction of $30 \%$, CO volume fraction of $60 \%, \mathrm{CO}_{2}$ volume fraction of $5 \%$ and $\mathrm{H}_{2} \mathrm{O}$ vapor volume fraction of $5 \%$. The total gas flow rate was $1 \mathrm{~L} / \mathrm{min}$ (nitrogen was the equilibrium gas), the adsorbent dose was $0.5 \mathrm{~g}$, and the bed temperature was set as $200{ }^{\circ} \mathrm{C}$.

The mercury removal efficiency ( $y$ ) of adsorbent was used as the evaluation index, the calculation formula was as follows:

$\eta=\frac{H_{\text {gin }}-H_{\text {gout }}}{H_{\text {gin }}}$

where Hgin and Hgout represent the inlet and outlet $\mathrm{Hg}^{0}$ concentrations (ng/L) respectively.

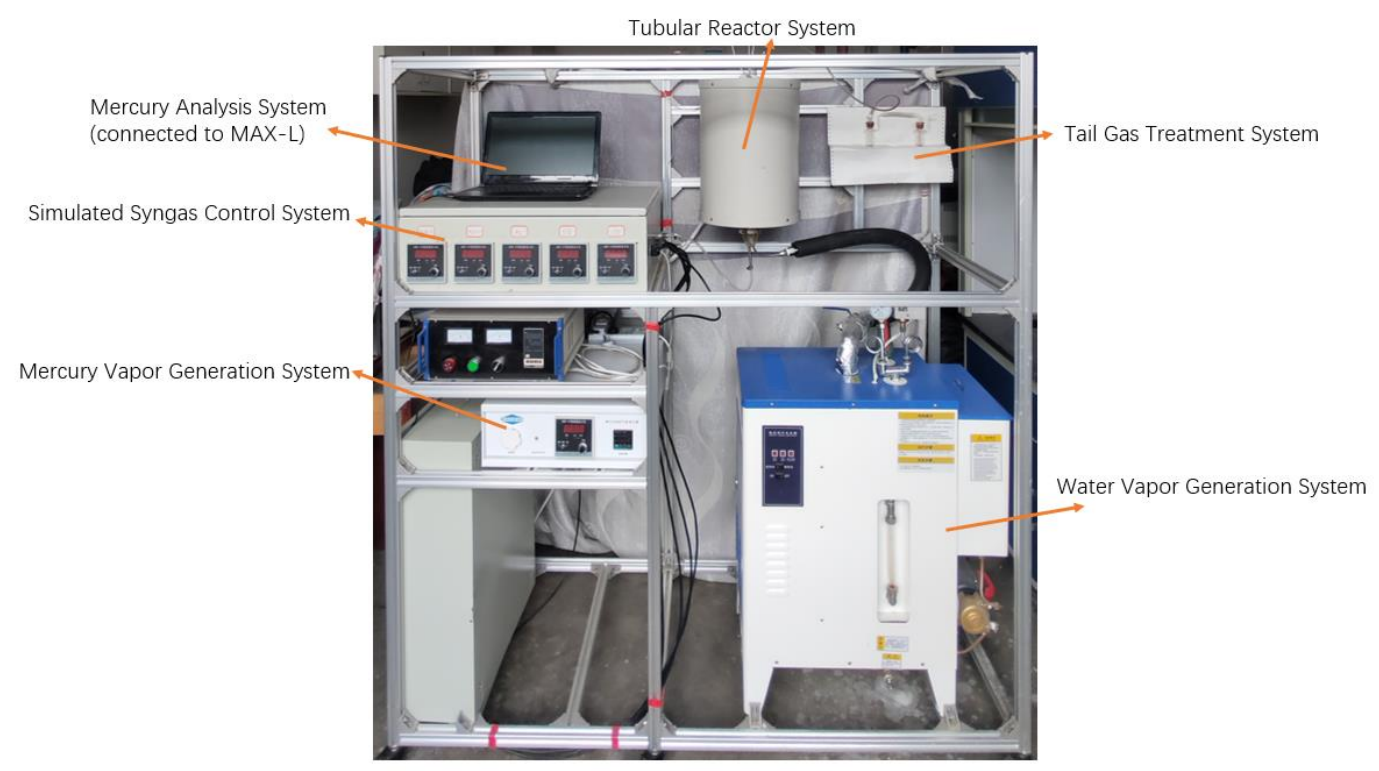

Fig. 4 Test bench of syngas mercury removal system

\section{Results and discussions}

\section{1 $\mathrm{CO}_{2}$ gasification of ultrafine pulverized coal particles}

It can be seen from the particle size distribution curves (as shown in Fig. 5a) and microscopic appearance (as shown in Fig. 5b) that the average particle sizes for sample $1 \#, 2 \#$ and $3 \#$ were smaller than sample $4 \#$ and $5 \#$. Further, the surface for $4 \#$ and $5 \#$ was smooth, while the surface for $1 \#, 2 \#$ and $3 \#$ was rather rough. The rough surface would promote the gasification process and enhance the reaction activity. The five gasification conversion factor $(\alpha)$ curves for samples with different particle sizes (as shown in Fig. 5c) almost overlapped when the temperature was lower than $850{ }^{\circ} \mathrm{C}$. However, when the temperature was higher than $850{ }^{\circ} \mathrm{C}$, there were significant differences for coal samples with different particle sizes. As for the effect of particle size on the gasification conversion factor, it can be found that the smaller the particle size, the larger the value of conversion factor. According to the plot of $\ln \left(\beta / T^{2}\right)$ vs $1 / T$ at a particular conversion factor $(\alpha)$ (as shown in Fig. 5d), a linear equation with the slope of $-E / R$ and intercept of $\ln \left(k_{0} R / E\right)+0.6075$ can be fitted to give the values of activation energy, 
pre-exponential factor, and correlation coefficient $\left(\mathrm{R}^{2}\right)$. The calculated values of correlation coefficient for all five samples are all higher than 0.97 , showing that the Miura-Maki model apply to Shenhua bituminous coal for gasification kinetic analysis.

\subsection{Predicted DTG model}

Fig. 6 depicts the $T(t), 1-\alpha(t), D T G(t)$, and $\operatorname{DTG}(\alpha)$ profiles for the Hulunbeier lignite coal. As shown in Fig. 6 (b) and (c), the weight loss ratio 1- $\alpha$ and the reaction rate $D T G(t)$ exhibit a regular distribution as the combustion temperature increases. The peaks in the $D T G(\alpha)$ profiles shown in Fig. 6 (d) can be observed when the burnout ratio $\alpha$ is around 0.1 , which was also observed by Bhatia et al. (Bhatia and Perlmutter 1980) The authors proposed a random pore model (RPM), which stated that the reaction rate responded to the change in pore structure and that a positive relationship existed between changes in the reaction rate and pore superficial area. The changes in the pore superficial area were the result of the competition between the pore extension and the pore overlap. The pore extension benefited from the increase in pore superficial area while the result for the pore overlap was the opposite. At the beginning of char combustion, the pore extension dominated and the reaction rate increased rapidly with the increase in the pore superficial area. After the peak of the reaction rate occurred at $\alpha_{\max }$, the pore overlap began to dominate the reaction and the reaction rate decreased with the reduction in the pore superficial area. The peak of the reaction rate predicted by the RPM occurred at $0<\alpha_{\max }<0.393$, which matched the observations shown in Fig. 6 (d).

The $E(\alpha)$ and $A(\alpha)$ are obtained by Eqs. (5) and (6) and are shown in Fig. 7. The result shows that both the $E(\alpha)$ and $\log A(\alpha)$ exhibited a U-shaped with a gentle fluctuation in the range of $0.2<\alpha<0.9$. As the burnout ratio increased from 0 to 0.3 , the char began to burn and the combustion rate increased significantly. This resulted in the decrease in $\mathrm{E}$ and $\log \mathrm{A}$. As the combustion continued, the flammable matter burned first and heated the flame retardant matter. The combustion rate, $\mathrm{E}$, and $\log \mathrm{A}$ were relatively stable in the range of $0.2<\alpha<0.9$. As the

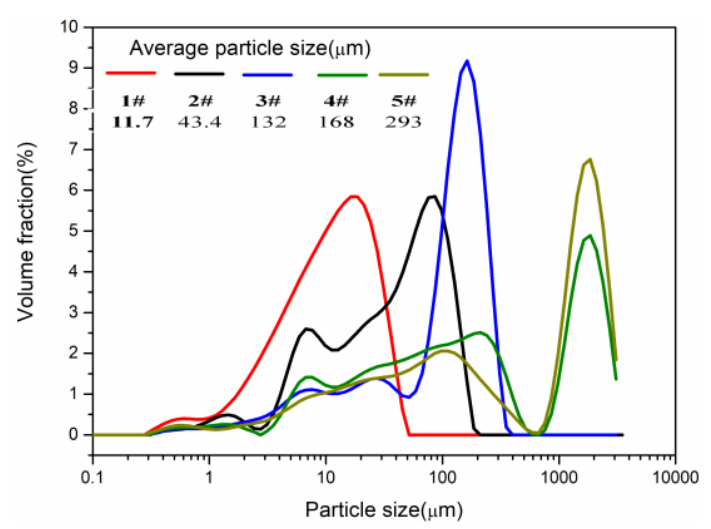

(a) particle size distribution curves

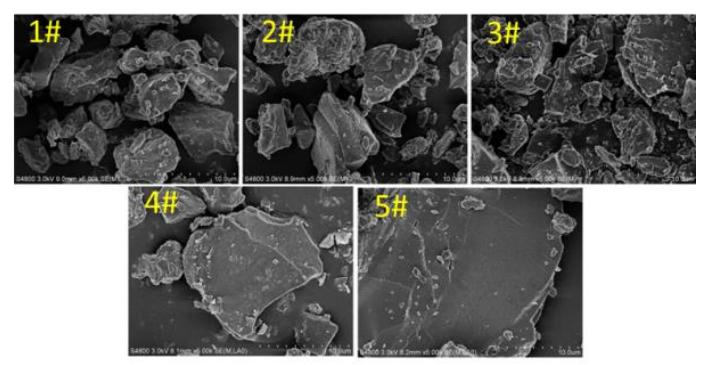

(b) the micro surface morphology

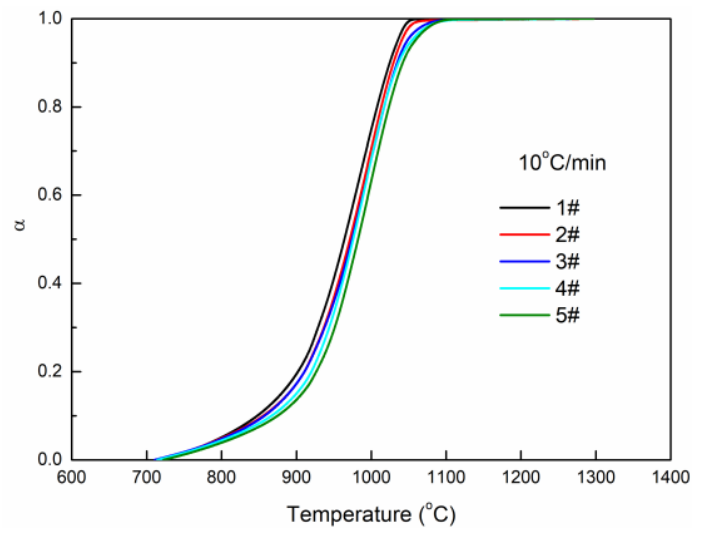

(c) gasification conversion factor curves

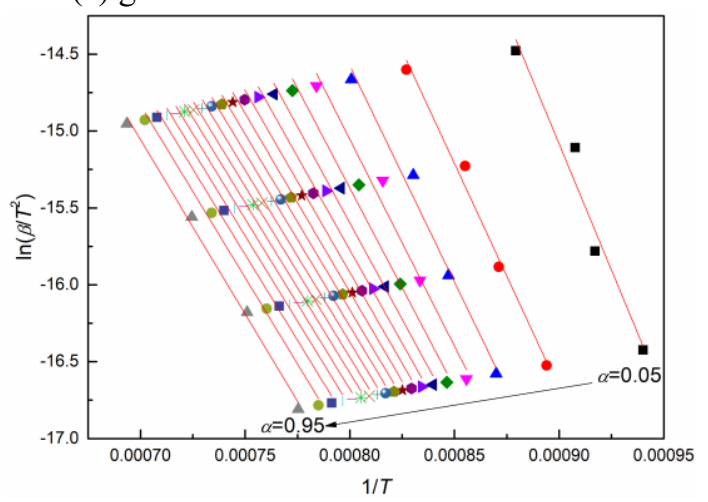

(d) the plots of $\ln \left(\beta / \mathrm{T}^{2}\right)$ vs $1 / \mathrm{T}$

Fig. 5 Experimental results of five coal samples with different particle sizes: (a) particle size

distribution curves; (b) the micro surface morphology; (c) gasification conversion factor curves; (d) the plots of $\ln \left(\beta / \mathrm{T}^{2}\right)$ vs $1 / \mathrm{T}$ at a particular conversion factor 


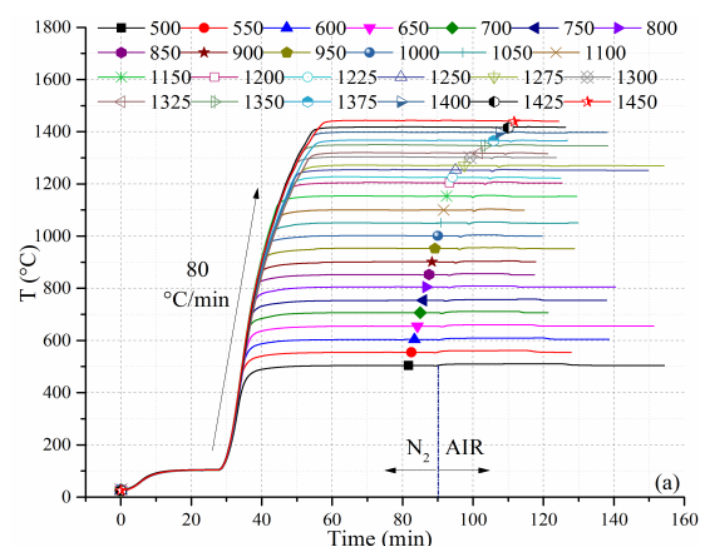

(a) $T(t)$

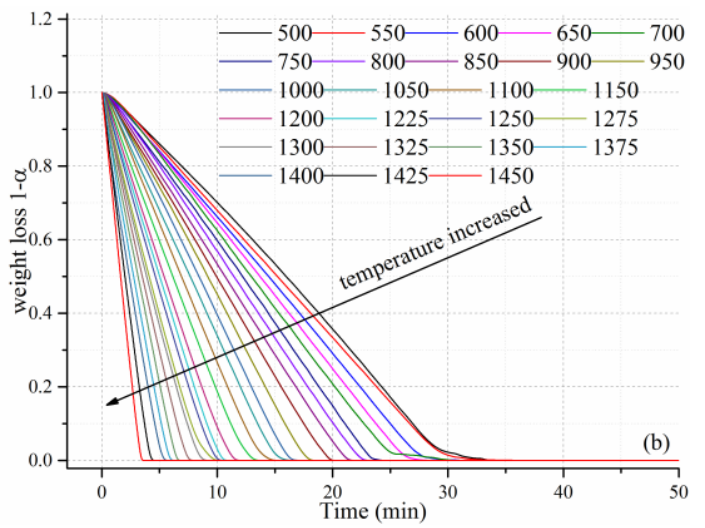

(b) $1-\alpha(t)$

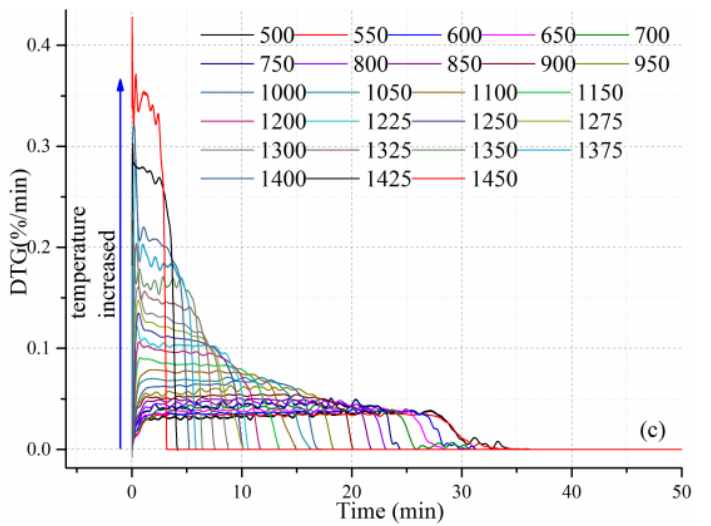

(c) DTG(t)

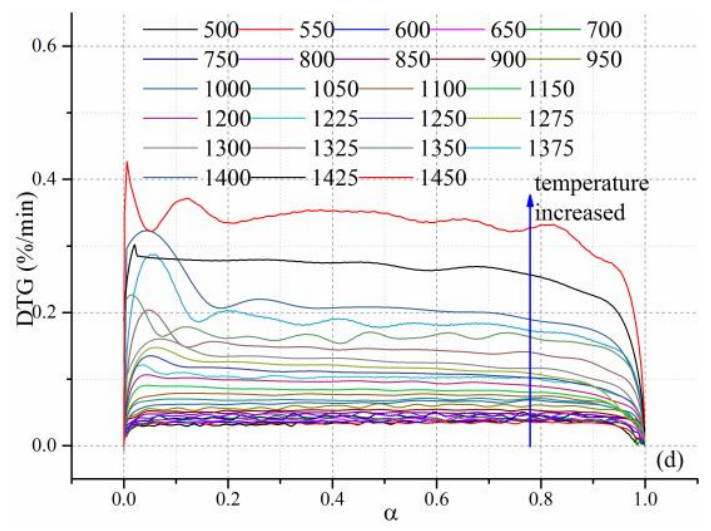

(d) $D T G(\alpha)$

Fig. 6 The (a) $T(t)$, (b) $1-\alpha(t)$, (c) $D T G(t)$, and (d) $D T G(\alpha)$ profiles for the Hulunbeier lignite coal.

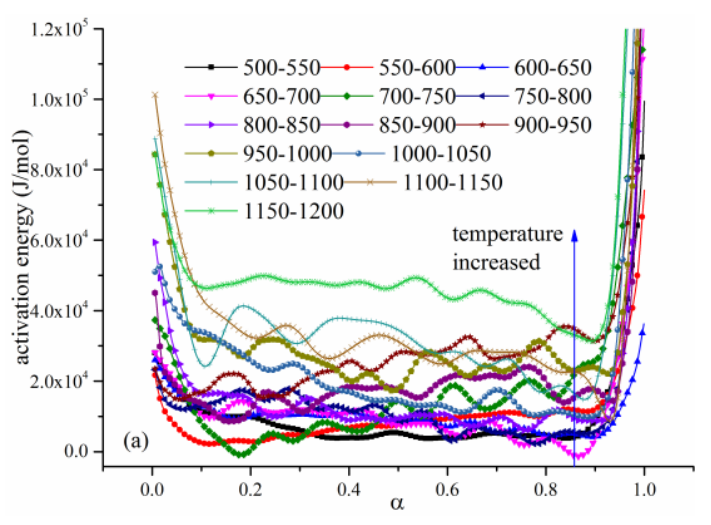

(a) activation energy $\mathrm{E}(\alpha)$

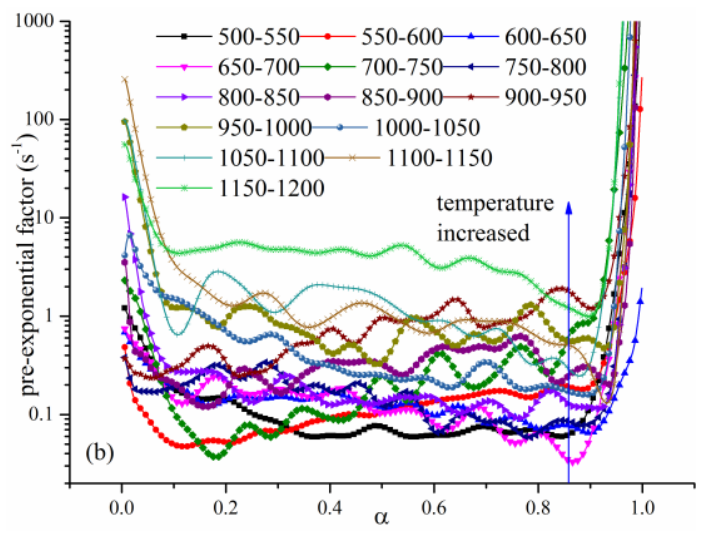

(b) pre-exponential factor $\mathrm{A}(\alpha)$

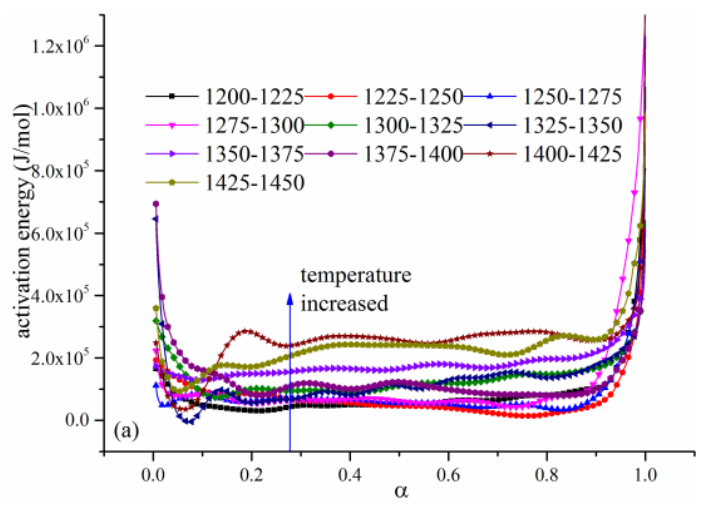

(a) activation energy $\mathrm{E}(\alpha)$

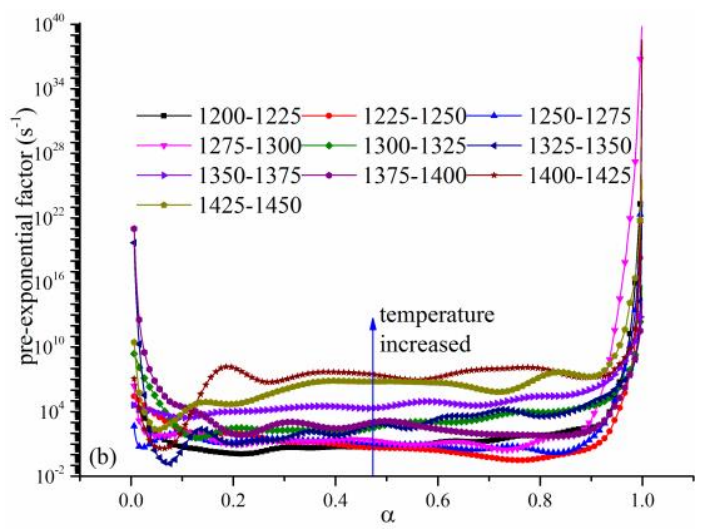

(b) pre-exponential factor $\mathrm{A}(\alpha)$

Fig. 7 The results for (a) activation energy $E(\alpha)$ and (b) pre-exponential factor $\mathrm{A}(\alpha)$. 
combustion temperature increased from $500{ }^{\circ} \mathrm{C}$ to $1200{ }^{\circ} \mathrm{C}$, the $\mathrm{E}$ and $\log \mathrm{A}$ curves progressively decreased in the range of $0.2<\alpha<0.9$ and increased in the range of $1200{ }^{\circ} \mathrm{C}$ to $1450{ }^{\circ} \mathrm{C}$. At the end of the combustion $0.9<\alpha<1$, the $\mathrm{E}$ and $\log \mathrm{A}$ curves increased exponentially for all temperatures.

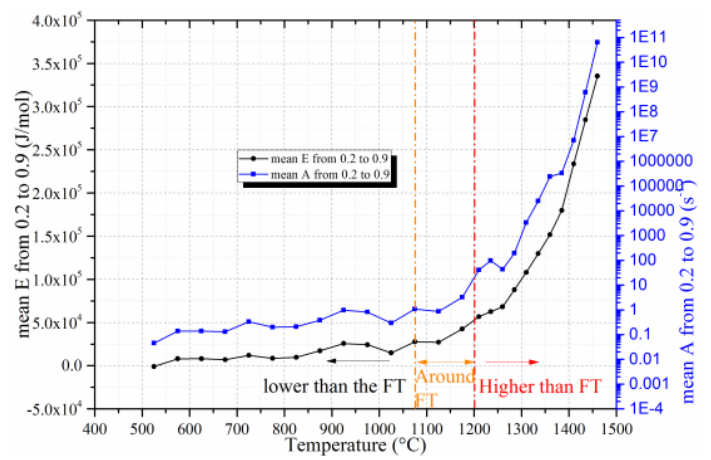

Fig. 8 The mean $E$ and $A$ values in the range of $0.2<\alpha<0.9$.

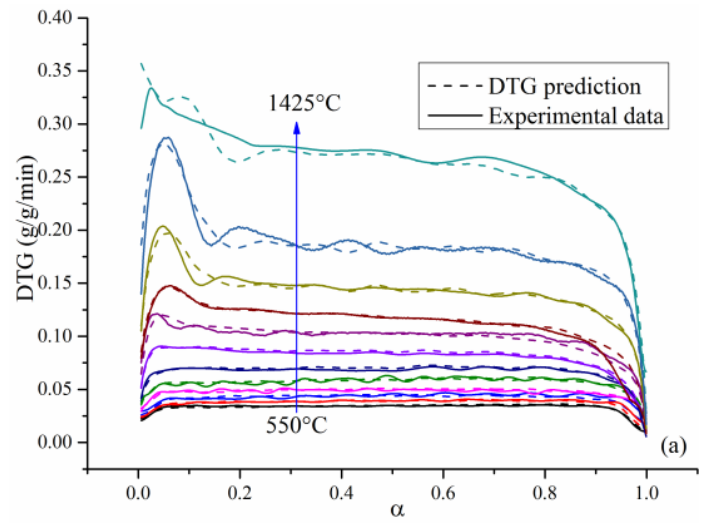

(a) predicted results and experimental results

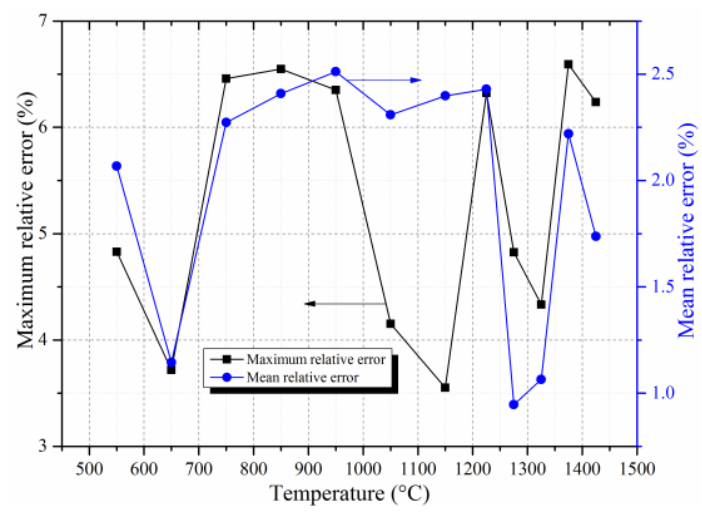

(b) error analysis in the range of $0.2<\alpha<0.9$.

Fig. 9 Comparison of (a) predicted results and experimental results and (b) error analysis in the range of $0.2<\alpha<0.9$

The $\mathrm{E}$ and $\log \mathrm{A}$ curves were stable in the range of $0.2<\alpha<0.9$ and the mean $\mathrm{E}$ and $\log \mathrm{A}$ in this range are shown in Fig. 8. At a combustion temperature lower than the AFT $\left(1160{ }^{\circ} \mathrm{C}\right)$, the $\mathrm{E}$ and $\log \mathrm{A}$ values fluctuated within the same order of magnitude. However, when the combustion temperature exceeded the AFT, the $\mathrm{E}$ and $\log \mathrm{A}$ values increased exponentially. It is noteworthy that the mean $\mathrm{E}$ and $\mathrm{A}$ values in the range of $0.2<\alpha<0.9$ varied with different temperatures, especially when the combustion temperature exceeded the AFT.

The values of $T_{1}$ and $T_{2}$ were identified as close as possible to avoid the effect of the AFT on the results of $\mathrm{E}$ and A. Using Eqs. (5), (6), and (7), the $D_{T G}(\alpha)$ at a combustion temperature of $T_{3}\left(\mathrm{~T}_{3}=\right.$ $\left.\left(\mathrm{T}_{1}+\mathrm{T}_{2}\right) / 2\right)$ was obtained. The comparison of the predicted results and the experimental results is shown in Fig. 9(a). Fig. 9(b) shows the error analysis in the range of $0.2<\alpha<0.9$. The predicted DTG curves fit the experimental data well. The maximum and mean relative errors were less than $6.5 \%$ and $2.5 \%$, respectively. This indicated that the predicted DTG model proposed in this study was validated to predict the char combustion in the TGA; the modle performed especially well for high-temperature $\left(\mathrm{T}>1200{ }^{\circ} \mathrm{C}\right)$ char combustion.

\section{$3.3 \mathrm{H}_{2} \mathrm{~S}-\mathrm{CO}_{2}$ removal}

The composition of the product gas is listed in

Table 3. The steam was removed by cooling before the evaluation. It is seen that the concentration of $\mathrm{CO}_{2}$ was lower than 500 ppm, meaning $99.9 \%$ of the $\mathrm{CO}_{2}$ was captured by the adsorbent. The concentration of $\mathrm{H}_{2} \mathrm{~S}$ was lower than the detection accuracy of chromatographic $(0.1 \mathrm{ppm}) . \quad \mathrm{H}_{2} \mathrm{~S}$ removing by activated carbon seems to be feasible. After running for several months, the $\mathrm{H}_{2} \mathrm{~S}$ did not penetrate the adsorption bed, indicating the adsorption of $\mathrm{H}_{2} \mathrm{~S}$ did be reversible. As a physical adsorbent, activated carbon could more or less adsorb all kinds of gas. Therefore, not only $\mathrm{CO}_{2}$ and $\mathrm{H}_{2} \mathrm{~S}$ but $\mathrm{CO}$ and $\mathrm{CH}_{4}$ were also partially removed during this process. Because $\mathrm{N}_{2}$ was adopted as the purging gas, the concentration of $\mathrm{N}_{2}$ is a bit higher than the feed gas. Small amount of inert gas is acceptable when the $\mathrm{H}_{2}$ is used in IGCC and IGFC. 
Table 3 Working condition and purification outcomes of 8-6-1 ETPSA

\begin{tabular}{cccc}
\hline Temperature & Pressure & Flow rate & Product gas composition (dry) \\
\hline \multirow{2}{*}{$170^{\circ} \mathrm{C}$} & $2 \mathrm{MPa}$ & $5.7 \mathrm{Nm}^{3} / \mathrm{h}$ & $1 \sim 2 \% \mathrm{~N}_{2},<500 \mathrm{ppm} \mathrm{CO}_{2},<0.1 \% \mathrm{CO},<0.1 \mathrm{ppm} \mathrm{H}_{2} \mathrm{~S}$, \\
& & $<100 \mathrm{ppm} \mathrm{CH}_{4}, \mathrm{H}_{2}$ as balance gas \\
\hline
\end{tabular}

The $\mathrm{H} 2$ recovery rate during this purification process is $97 \%$, which is much higher than regular PSA (Lopes et al. 2011; Shen et al. 2012; Wang et al. 2012). It could be attributed to the introduction of vacuum desorption and steam rinse. In order to explore the influence of rinse and vacuum desorption, we changed the cycle procedure and evaluated the corresponding product gas compositions and recovery rates. The case shown above is the best one and is named as Case 4. The others are Case 1-3. The results are as shown in Table 4. The conditions and parameters were same to Case 4 if not mentioned. We regulated the cycle time to make the product purity close Case 4 so that the recovery rate could represent the separation efficiency. The time length of each step is also given in Fig. 2.

Table 4 Separation efficiencies of different cases with and without vacuum desorption and steam

\begin{tabular}{cccccccc}
\hline \multicolumn{7}{c}{ rinse } \\
\hline Case & Temperature & Flow rate & Cycle time & $\mathrm{H}_{2} \mathrm{~S}$ & $\mathrm{CO}_{2}$ & $\mathrm{H}_{2}$ recovery & Procedure \\
\hline 1 & $170^{\circ} \mathrm{C}$ & $5.2 \mathrm{Nm}^{3} / \mathrm{h}$ & $456 \mathrm{~s}$ & $<0.1 \mathrm{ppm}$ & $\sim 0.3 \%$ & $79.3 \%$ & Without $\mathrm{V}$ and $\mathrm{RH}$ \\
2 & $120^{\circ} \mathrm{C}$ & $6.8 \mathrm{Nm}^{3} / \mathrm{h}$ & $544 \mathrm{~s}$ & $<0.1 \mathrm{ppm}$ & $\sim 0.3 \%$ & $86.4 \%$ & Without $\mathrm{V}$ and $\mathrm{RH}$ \\
3 & $170^{\circ} \mathrm{C}$ & $5.7 \mathrm{Nm}^{3} / \mathrm{h}$ & $360 \mathrm{~s}$ & $<0.1 \mathrm{ppm}$ & $\sim 0.3 \%$ & $93.3 \%$ & Without V \\
\hline
\end{tabular}

After replacing $\mathrm{V}$ and $\mathrm{RH}$ with $\mathrm{PG}$ and $\mathrm{AD}$ respectively, the $\mathrm{H}_{2}$ recovery decreased to $79.3 \%$, which was close to some regular PSA operated at normal temperatures(Mivechian and Pakizeh 2013; Rahimpour et al. 2013). Considering the adsorption capacity of activated carbon would deteriorate with the rising temperature, we set the temperature as $120{ }^{\circ} \mathrm{C}$ and the $\mathrm{H}_{2}$ recovery rate is thus improved in Case 2. Then we added the steam rinse, $\mathrm{H}_{2}$ recovery increasing to over $90 \%$ immediately. It means steam rinse was a significant factor. However, although the cycle time of Case 3 is shorter, the $\mathrm{CO}_{2}$ concentration in product gas was up to $0.3 \%$, which was much higher than Case 4. It was mainly due to the remained impurities in adsorption bed after regeneration steps. Vacuum desorption is demonstrated to be effective on the aspect of promoting adsorbent regeneration and compensate the defect in desorption kinetic performance. The introduction of vacuum desorption will result in extra power consumption and the cost of high pressure steam in rinse step will also lead to more energy consumption. Hence the energy efficiency of ETPSA should be further discussed in our following studies.

\subsection{Syngas mercury removal}

\subsection{1 a- $\mathrm{Al}_{2} \mathrm{O}_{3}$ measurement}

The a- $\mathrm{Al}_{2} \mathrm{O}_{3}$ was carrier in the experiments, and the parameters as shown in

Table 5. It can be seen that specific surface area of $\mathrm{a}-\mathrm{Al}_{2} \mathrm{O}_{3}$ may reach $237 \mathrm{~m}^{2} / \mathrm{g}$, which was very large, and $\mathrm{a}-\mathrm{Al}_{2} \mathrm{O}_{3}$ was the ideal carrier material.

Table 5 Properties of carrier $\mathrm{a}-\mathrm{Al}_{2} \mathrm{O}_{3}$ 
Smple $\quad$ Size $/ \mathrm{mm} \quad \begin{gathered}\text { specific surface area } \\ \left(\mathrm{m}^{2} / \mathrm{g}\right)\end{gathered}$

\begin{tabular}{lll}
\hline $\mathrm{a}-\mathrm{Al}_{2} \mathrm{O}_{3}$ & 1.5 & 237
\end{tabular}

\subsubsection{Mercury removal test of the carrier}

Mercury removal experiments were carried out at different temperatures with $\mathrm{a}-\mathrm{Al}_{2} \mathrm{O}_{3}$, which was not impregnated with the active component. The experimental result was shown in Fig. 10. It could be seen that the temperature at $150{ }^{\circ} \mathrm{C}$, mercury removal efficiency was about $5 \%$. However, mercury removal efficiency decreased with the increase of temperature, when the temperature reached $400{ }^{\circ} \mathrm{C}$, the mercury removal efficiency was almost zero. And the reason was mainly due to the $\mathrm{a}-\mathrm{Al}_{2} \mathrm{O}_{3}$ full of the microchannel had very large specific surface area, which possessed strong physical adsorption capacity. So the $\mathrm{a}-\mathrm{Al}_{2} \mathrm{O}_{3}$ presented the mercury removal capacity in lower temperature. But the $\mathrm{a}-\mathrm{Al}_{2} \mathrm{O}_{3}$ don't possess chemical adsorption capacity, the mercury removal capacity was lost when the temperature reached $400{ }^{\circ} \mathrm{C}$.

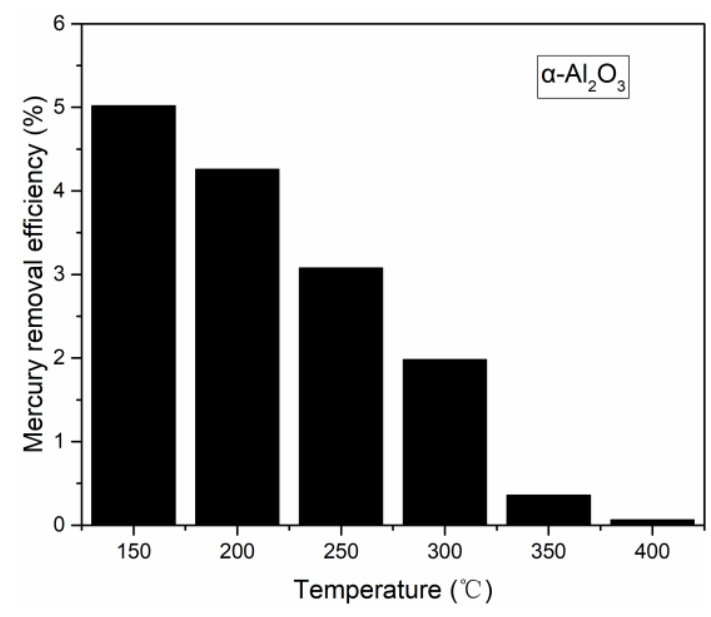

Fig. 10 Mercury removal performance of a- $\mathrm{Al}_{2} \mathrm{O}_{3}$ at different temperatures

\subsubsection{Evaluation of prepared adsorbents}

The prepared $\mathrm{Mn}_{2} \mathrm{O}_{3} / \mathrm{Al}_{2} \mathrm{O}_{3}, \mathrm{Co}_{2} \mathrm{O}_{3} / \mathrm{Al}_{2} \mathrm{O}_{3}$ and $\mathrm{Fe}_{2} \mathrm{O}_{3} / \mathrm{Al}_{2} \mathrm{O}_{3}$ loaded with active components were evaluated under the simulated gas condition of $200^{\circ} \mathrm{C}$ respectively. The evaluation results were shown in Fig. 11 Fig. 13 .

As shown in Fig. 11 Fig. 13, the mercury removal efficiency of prepared $\mathrm{Mn}_{2} \mathrm{O}_{3} / \mathrm{Al}_{2} \mathrm{O}_{3}$ could reach $90.4 \%$ in the first $10 \mathrm{~min}$, and then slowly decreased, and finally the mercury

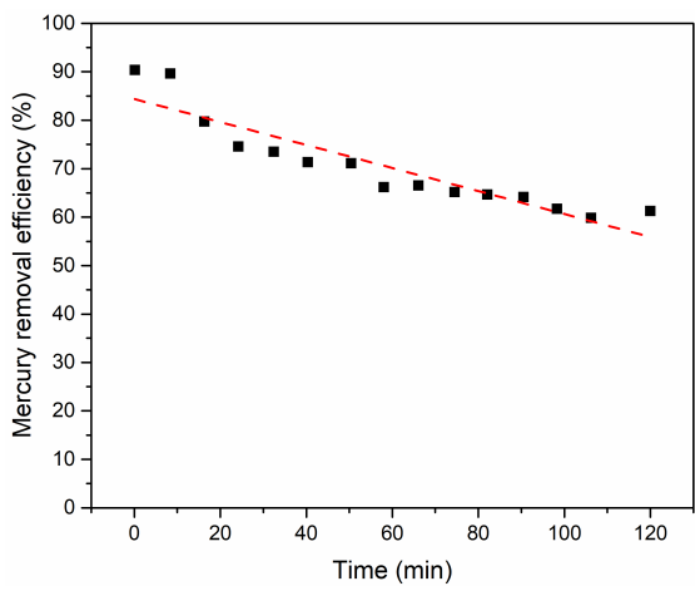

Fig. 11 The test curve of mercury removal performance of $\mathrm{Mn}_{2} \mathrm{O}_{3} / \mathrm{Al}_{2} \mathrm{O}_{3}$

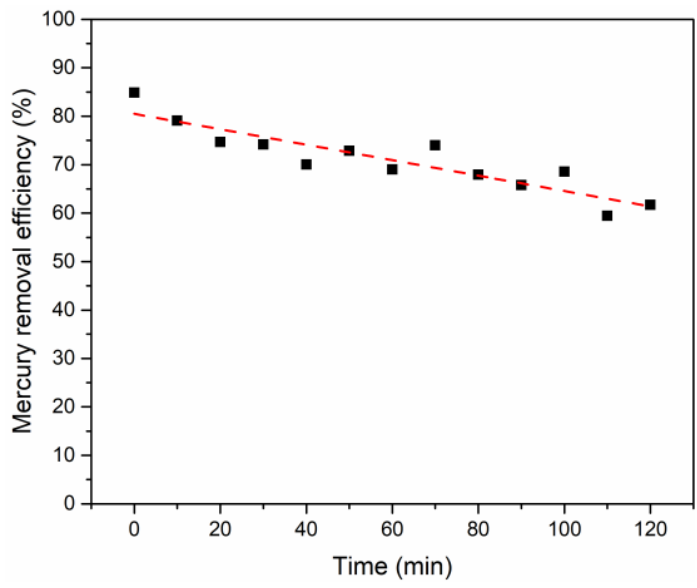

Fig. 12 The test curve of mercury removal performance of $\mathrm{Co}_{2} \mathrm{O}_{3} / \mathrm{Al}_{2} \mathrm{O}_{3}$

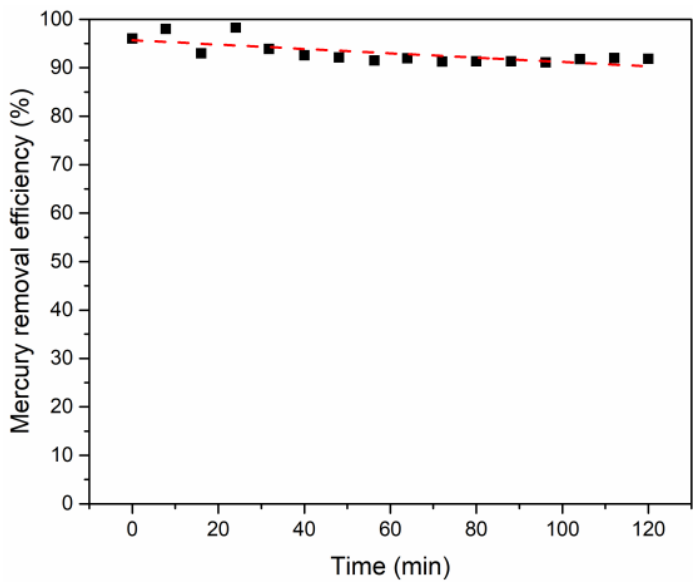

Fig. 13 The test curve of mercury removal performance of $\mathrm{Fe}_{2} \mathrm{O}_{3} / \mathrm{Al}_{2} \mathrm{O}_{3}$ 
removal efficiency was stable at about $60 \%$. The initial mercury removal efficiency of the prepared $\mathrm{Co}_{2} \mathrm{O}_{3} / \mathrm{Al}_{2} \mathrm{O}_{3}$ was $86 \%$, and the final mercury removal efficiency was stable at about $60 \%$.The mercury removal agent $\mathrm{Fe}_{2} \mathrm{O}_{3} / \mathrm{Al}_{2} \mathrm{O}_{3}$ had the best mercury removal performance, with the initial mercury removal efficiency reaching $95.4 \%$. In the two-hour test, the mercury removal agent was maintained at about $90 \%$ with no attenuation.

It could be seen in Fig. 11 and 12, the mercury removal efficiency of $\mathrm{Mn}_{2} \mathrm{O}_{3} / \mathrm{Al}_{2} \mathrm{O}_{3}$ and $\mathrm{Co}_{2} \mathrm{O}_{3} / \mathrm{Al}_{2} \mathrm{O}_{3}$ both showed very big promotion compared to pure $\mathrm{Al}_{2} \mathrm{O}_{3}$, which presented that the way of the original physical adsorption was changed, and speculated that physical adsorption and chemical adsorption synergy effected existed (Huo et al. 2017; Mao et al. 2018), the mechanism was speculated as follows $\left(\mathrm{Mn}_{2} \mathrm{O}_{3}\right.$ as example):

$$
\begin{aligned}
& \mathrm{Mn}_{2} \mathrm{O}_{3}+3 \mathrm{H}_{2} \rightarrow 2 \mathrm{Mn}^{2}+3 \mathrm{H}_{2} \mathrm{O} \\
& \mathrm{Mn}_{2} \mathrm{O}_{3}+3 \mathrm{CO} \rightarrow 2 \mathrm{Mn}^{0}+3 \mathrm{H}_{2} \mathrm{O} \\
& \mathrm{Mn}^{2}+\mathrm{H}_{g}{ }^{0} \rightarrow \mathrm{Mn}-\mathrm{H}_{g}
\end{aligned}
$$

Meanwhile, the mercury removal efficiency of $\mathrm{Mn}_{2} \mathrm{O}_{3} / \mathrm{Al}_{2} \mathrm{O}_{3}$ and $\mathrm{Co}_{2} \mathrm{O}_{3} / \mathrm{Al}_{2} \mathrm{O}_{3}$ both displayed the trend of decreasing during $2 \mathrm{~h}$ test, finally the mercury removal efficiency was stable at a certain value, which suggested that the reaction of $\mathrm{Hg}^{0}$ and the active component reached reaction equilibrium.

The mercury removal mechanism of $\mathrm{Fe}_{2} \mathrm{O}_{3} / \mathrm{Al}_{2} \mathrm{O}_{3}$ was obviously different from that of $\mathrm{Mn}_{2} \mathrm{O}_{3} / \mathrm{Al}_{2} \mathrm{O}_{3}$ and $\mathrm{Co}_{2} \mathrm{O}_{3} / \mathrm{Al}_{2} \mathrm{O}_{3}$. The mechanism was speculated as follows:

$3 \mathrm{H}_{2} \mathrm{~S}+\mathrm{Fe}_{2} \mathrm{O}_{3} \rightarrow 2 \mathrm{FeS} x+\mathrm{Sad}+3 \mathrm{H}_{2} \mathrm{O}$

$H_{g}{ }^{0}+\mathrm{Sad} \rightarrow \mathrm{H}_{g} \mathrm{~S}$

It could be seen that because $\mathrm{H}_{2} \mathrm{~S}$ existed in coal gasification syngas improved the mercury removal efficiency and stability of $\mathrm{Fe}_{2} \mathrm{O}_{3} / \mathrm{Al}_{2} \mathrm{O}_{3}$ mercury removal agent, $\mathrm{H}_{2} \mathrm{~S}$ replaced the combination of transition metal oxides with $\mathrm{Hg}^{0}$, making its mercury removal efficiency reached more than $90 \%$.

\section{Conclusions}

In this paper, the gasification reaction characteristics of ultrafine coal particles, the formation mechanism of pollutants, and $\mathrm{H}_{2} \mathrm{~S}$ and $\mathrm{CO}_{2}$ simultaneous removal in the process of IGFC were studied. The following conclusions can be obtained.

(1) The surface became coarser with the decrease of the particle size of coal sample, which would promote the gasification process and improve the reaction activity. It was proved that the Miura-Maki model appropriate to perform gasification kinetics of Shenhua bituminous coal. The value of activation energy decreased with the decrease of the particle size of coal samples.

(2) A database of the kinetic characteristics functions of char combustion was established and a DTG model was established. The maximum and mean relative errors were less than $6.5 \%$ and $2.5 \%$, respectively. The predicted DTG curves fit the experimental data well because the effect of the AFT on the E and A values was taken into account.

(3) A small scale ETPSA rig was built in an ammonia plant and on-site syngas $\mathrm{H}_{2} \mathrm{~S}-\mathrm{CO}_{2}$ simultaneous removal was realized. An 8-6-1 cycle procedure with steam rinse and vacuum desorption was designed and demonstrated to be efficient. The concentration of $\mathrm{CO}_{2}$ and $\mathrm{H}_{2} \mathrm{~S}$ in product gas was lower than $500 \mathrm{ppm}$ and 0.1 ppm respectively, indicating the removal rate was over $99.9 \%$. The corresponding $\mathrm{H}_{2}$ recovery rate was $97 \%$. The importance of steam rinse and vacuum desorption was verified after changing the cycle procedure. However, the energy efficiency of ETPSA should be analyzed in detail in the future.

(4) Three kinds of mercury removal adsorbents were prepared, $\mathrm{Mn}_{2} \mathrm{O}_{3} / \mathrm{Al}_{2} \mathrm{O}_{3}$, $\mathrm{Co}_{2} \mathrm{O}_{3} / \mathrm{Al}_{2} \mathrm{O}_{3}$, $\mathrm{Fe}_{2} \mathrm{O}_{3} / \mathrm{Al}_{2} \mathrm{O}_{3}$, which showed 
different degrees of mercury removal performance. Among them, the mercury removal efficiency of $\mathrm{Fe}_{2} \mathrm{O}_{3} / \mathrm{Al}_{2} \mathrm{O}_{3}$ was basically stable at more than $90 \%$ under the $2 \mathrm{~h}$ condition of $200{ }^{\circ} \mathrm{C}$ medium temperature test. The use of transition metal oxides as mercury removal adsorbents in coal gasification syngas had great potential and was the main direction of the research on mercury removal in IGFC gas purification system.

\section{Acknowledgements:}

This work was financially supported by National Key R\&D Program of China (2017YFB0601900).

\section{References}

Anthony DB, Howard JB (1976) Coal devolatilization and hydrogastification. AIChE Journal 22(4):625-656.

Bhatia SK, Perlmutter D (1980) A random pore model for fluid-solid reactions: I. Isothermal, kinetic control. AIChE Journal 26(3):379-386.

Chaubey R, Sahu S, James OO, Maity S (2013) A review on development of industrial processes and emerging techniques for production of hydrogen from renewable and sustainable sources. Renewable \& Sustainable Energy Reviews 23:443-462.

Cloke M, Wu T, Barranco R, Lester E (2003) Char characterisation and its application in a coal burnout model. Fuel 82(15):1989-2000.

Denton, L D (2014) An update on RTI's warm syngas cleanup demonstration project. Paper presented at the Gasification Technologies Conference, Washington, DC.

Dincer I, Acar C (2015) Review and evaluation of hydrogen production methods for better sustainability. International journal of hydrogen energy 40(34):11094-11111.

Gazzani M, Macchi E, Manzolini G (2013) CO2 capture in integrated gasification combined cycle with SEWGS - Part A: Thermodynamic performances. Fuel 105:206-219.

Granite EJ, Pennline HW, Hargis RA (2000)

Novel Sorbents for Mercury Removal from

Flue Gas. Industrial and Engineering

Chemistry Research 39(4):1020.

Gupta, Raghubir (2010) Scaleup and Commercialization of Warm Syngas Cleanup Technology with Carbon Capture and Storage. Paper presented at the Gasification Technologies Conference, Washington, DC.

Hao P, Liu Z, Shi Y, Li S, Cai N (2019) Characteristics of activated carbon in elevated-temperature pressure swing adsorption desulfurization. Adsorption 25(6):1-8.

Hecker WC, Madsen PM, Sherman MR, Allen JW, Sawaya RJ, Fletcher TH (2003) High-pressure intrinsic oxidation kinetics of two coal chars. Energy \& fuels 17(2):427-432.

Huo Q, Qi D, Ye L, Han L, Chang L (2017) The Preparation of $\mathrm{PdFe} / \mathrm{Al}_{2} \mathrm{O}_{3}$ Mercury Removal Sorbent by Chemical Co-Precipitation. Chemical Reaction Engineering \& Technology 33(5):450-457.

Hurt R, Sun J-K, Lunden M (1998a) A kinetic model of carbon burnout in pulverized coal combustion. Combustion and Flame 113(1):181-197.

Hurt R, Sun JK, Lunden M (1998b) A Kinetic Model of Carbon Burnout in Pulverized Coal Combustion. Combustion \& Flame 113(1):181-197.

Krishnamoorthy V, Pisupati SV (2015) A Critical Review of Mineral Matter Related Issues during Gasification of Coal in Fixed, Fluidized, and Entrained Flow Gasifiers. Energies 8(9):10430-10463.

Li H, Wu CY, Li Y, Zhang J (2011) $\mathrm{CeO}_{2}-\mathrm{TiO}_{2}$ Catalysts for Catalytic Oxidation of Elemental Mercury in Low-Rank Coal 
Combustion Flue Gas. Environmental Science \& Technology 45(17):7394-7400.

Li S, Hao P, Zhu X, Shi Y, Jiang H (2019) On-site demonstration of an elevated temperature hydrogen clean-up unit for fuel cell applications. Adsorption 25(8):1683-1693.

Liu B, Tian J (2012) Progress in effects of coal properties on entrained-flow gasification. Chemical Industry and Engineering Progress 31(10):2191-2196(in chinese).

Liu J, Jiang X, Han X, Shen J, Zhang H (2014) Chemical properties of superfine pulverized coals. Part 2. Demineralization effects on free radical characteristics. Fuel 115:685-696.

Liu T (2016) Mechanism and experimental study on removal of elemental mercury by iron oxide. Dissertation, Huazhong university of science and technology

Liu X (2015) Theoretical study of removal of $. \gamma-\mathrm{Al}_{2} \mathrm{O}_{3}$ for hydrogen sulfide and mercury. Dissertation, Taiyuan university of technology

Liu Y, Kelly DJA, Yand H, Lin CCH, Kuznicki SM, Xu Z (2008) Novel Regenerable Sorbent for Mercury Capture from Flue Gases of Coal-Fired Power Plant. Environmental Science \& Technology 42(16):6205-6210.

Lopes FVS, Grande CA, Rodrigues AE (2011) Activated carbon for hydrogen purification by pressure swing adsorption: Multicomponent breakthrough curves and PSA performance. Chemical Engineering Science 66(3):303-317.

Luo L, Yao W, Liu J, Zhang H, Ma J, Jiang X (2019) The effect of the grinding process on pore structures, functional groups and release characteristic of flash pyrolysis of superfine pulverized coal. Fuel 235:1337-1346.

Mao J, Zhou J, Li X, Zhou Q, Cao H (2018) Mechanism of Mercury $R$ emoval in Syngas by Co-modified Activated Coke with $\mathrm{H}_{2} \mathrm{~S}$. Chinese Journal of Applied Chemistry 35(12):106-115(in chinese).

Miura K, Maki T (1998) A Simple Method for Estimating $\mathrm{f}(\mathrm{E})$ and $\mathrm{k} 0(\mathrm{E})$ in the Distributed Activation Energy Model. Energy \& Fuels 12(5):864-869.

Mivechian A, Pakizeh M (2013) Hydrogen recovery from Tehran refinery off-gas using pressure swing adsorption,gas absorption and membrane separation technologies:Simulation and economic evaluation. Korean Journal of Chemical Engineering 30(4):937-948.

Pavlish JH, Sondreal EA, Mann MD, Olson ES, Benson SA (2003) Status review of mercury control options for coal-fired power plants. Fuel Processing Technology 82(2):89-165.

Peng S, Han M (2009) Development of Coal/Carbon Based Solid Oxide Fuel Cel. Chinese Journal of Nature 31(4):187-192(in chinese).

Pilling MJ, Seakins PW (1995) Reaction Kinetics. Oxford University Press, New York

Pitt G (1962) The kinetics of the evolution of volatile products from coal. Fuel 41(3):267-274.

Rahimpour MR, Ghaemi M, Jokar SM, Dehghani O, Jafari M, S.Amiri, S.Raeissi (2013) The enhancement of hydrogen recovery in PSA unit of domestic petrochemical plant. Chemical Engineering Journal Lausanne

Reed GP, Ergudenler A, Grace JR, Watkinson AP, Herod AA, Dugwell D, Kandiyoti R (2001) Control of gasifier mercury emissions in a hot gas filter: the effect of temperature. Fuel 80(5):623-634.

Shen C, Liu Z, Li P, Yu J (2012) Two-Stage VPSA Process for $\mathrm{CO}_{2}$ Capture from Flue Gas Using Activated Carbon Beads. Industrial \& Engineering Chemistry Research 51:5011-5021.

Sima-Ella E, Yuan G, Mays T (2005) A simple kinetic analysis to determine the intrinsic reactivity of coal chars. Fuel 
84(14):1920-1925.

Sun X, Chen J (1991) Physical and chemical basis of pulverized coal combustion. HUST Press, Wuhan

Wang L, Liu Z, Li P, Wang J, Yu J (2012) $\mathrm{CO}_{2}$ capture from flue gas by two successive VPSA units using 13XAPG. Adsorption 18(5-6):445-459.

Wen X, Li C, Fan X, Gao H, Zhao Y (2011) Experimental Study of Gaseous Elemental Mercury Removal with $\mathrm{CeO}_{2} / \mathrm{y}-\mathrm{Al}_{2} \mathrm{O}_{3}$. Energy \& Fuels 25(7):2939-2944.

Wiheeb AD, Shamsudin IK, Ahmad MA, Murat MN, Kim J, Othman MR (2013) Present technologies for hydrogen sulfide removal from gaseous mixtures. Reviews in
Chemical Engineering 29(6):449-470.

Xu S, Wei S (1999) An analysis and evaluation of the gas clean-up process equipment and technical equipment characteristics in four IGCC demonstration power plants. Clean Coal Technology 5(1):47-51(in chinese).

Yu CH, Huang CH, Tan CS (2012) A Review of $\mathrm{CO}_{2}$ Capture by Absorption and Adsorption. Aerosol and Air Quality Research 12(5):745-769.

Zhang X, Nie Q, Sun S (2000) A study of thermobalance model for the burning of blended coals. Journal of Engineering for Thermal Energy and power 15(4):356-359(in chinese). 